\title{
Performance in Publicly Funded Innovation Networks (PFINs): The role of inter- organisational relationships
}

Kreye, Melanie; Perunovic, Zoran

Published in:

Industrial Marketing Management

Link to article, DOI:

10.1016/j.indmarman.2019.11.018

Publication date:

2020

Document Version

Peer reviewed version

Link back to DTU Orbit

Citation (APA):

Kreye, M., \& Perunovic, Z. (2020). Performance in Publicly Funded Innovation Networks (PFINs): The role of inter-organisational relationships. Industrial Marketing Management, 86, 201-211.

https://doi.org/10.1016/j.indmarman.2019.11.018

\section{General rights}

Copyright and moral rights for the publications made accessible in the public portal are retained by the authors and/or other copyright owners and it is a condition of accessing publications that users recognise and abide by the legal requirements associated with these rights.

- Users may download and print one copy of any publication from the public portal for the purpose of private study or research.

- You may not further distribute the material or use it for any profit-making activity or commercial gain

- You may freely distribute the URL identifying the publication in the public portal

If you believe that this document breaches copyright please contact us providing details, and we will remove access to the work immediately and investigate your claim. 


\title{
Performance in Publicly Funded Innovation Networks (PFINs): The role of inter-organisational relationships
}

\author{
Melanie E. Kreye* \\ Department of Management, Technical University of Denmark \\ Zoran Perunovic \\ Jones Graduate School of Business, Rice University
}

Accepted for publication in: Industrial Marketing Management

Please cite as: Kreye, M.E. \& Perunovic, Z. (2020), Performance in Publicly Funded Innovation Networks (PFINs): The role of inter-organisational relationships, accepted to Industrial Marketing Management

* Corresponding author

\section{Author note:}

Associate Professor

Address: Produktionstorvet 424, 2800 Kgs. Lyngby, Denmark

Telephone: +4545256028

Email: mkreye@dtu.dk 


\title{
Performance in Publicly Funded Innovation Networks (PFINs): The role of inter-organisational relationships
}

\author{
Abstract \\ This research investigates how performance in Publicly Funded Innovation \\ Networks (PFINs) is affected by the inter-organisational relationships in terms of \\ alignment between network administration and participating organisations. Our \\ findings from a longitudinal embedded case study of a PFIN in the Nordic \\ maritime industry show two key insights. First, we identify three patterns of \\ inter-organisational relationships: functional (alignment between the self- \\ organised relationships by project partners and relationship requirements from \\ network administration), dysfunctional (contradictions between the self- \\ organised relationships by project partners and relationship requirements from \\ network administration), and anarchic (self-organised relationships by project \\ partners with a lack of direction or leadership). Second, we show that each of \\ these patterns of inter-organisational relationships have different effects on \\ performance factors. An unexpected emergent finding was the observation of \\ sub-circles of functional relationships within projects of dysfunctional \\ relationships aimed at circumventing the misaligned requirements of network \\ administration. We propose a conceptual framework detailing the effects of \\ these three relationship patterns on PFIN performance in terms of immediate \\ and long-term effects.
}

Keywords: innovation networks, inter-organisational relationships, collaboration, maritime industry, case study 


\section{Introduction}

Publicly Funded Innovation Networks (PFINs) are an increasing source of innovation aimed at solving societal and scientific challenges (Eklinder-Frick \& Åge, 2017;

Reypens, Lievens, \& Blazevic, 2016). PFINs often have a strategic aim in increasing the innovativeness of an area (industrial sector/geographic/type of organisations etc.) via the development of new technology, services or business models (Ritter \& Gemünden, 2003; Song, Cao, \& Zheng, 2016). Receiving their funding from public funding bodies such as the European Commission, PFINs are a tool to implement regional policy by funding targeted innovation activities. However, many PFINs have experienced difficulties in achieving performance where both effectiveness and efficiency can fall short of expectations (Cumming \& Fischer, 2012; Link \& Wright, 2015; Spanos \& Vonortas, 2012) because of PFIN's heavy administration apparatus, challenging the ability to achieve innovation objectives with the best use of public funding. Despite the importance of PFINs in practice, relatively little is known about the determinants of performance in these organisational structures.

One of the core challenges in PFINs (and innovation networks in general) is the management of inter-organisational relationships and their longitudinal evolution (Nordin, Ravald, Möller, \& Mohr, 2018) with some research claiming that relationships are the critical mechanism for technological innovation (La Rocca \& Snehota, 2014). Despite the acknowledgement of the importance of inter-organisational relationships in achieving performance in innovation networks (La Rocca \& Snehota, 2014; Medlin \& Törnroos, 2015; Nordin et al., 2018), little is known about this link. Specifically, little theory exists regarding the longitudinal effects of inter-organisational relationships in PFINs through their formation and execution on the innovation performance. 
Managing inter-organisational relationships in innovation networks remains a challenging task because of the diverse nature of the stakeholders (Leena AarikkaStenroos, Sandberg, \& Lehtimäki, 2014) with potentially competing objectives (Planko, Chappin, Cramer, \& Hekkert, 2017). In PFINs, network managers need to align the complex characteristics of inter-organisational relationships, managing the trade-offs between centralised pressures such as political incentives and policies, as well as decentralised motives of achieving innovation and business outcomes. This trade-off can be visible in the network of many PFINs. Because a public funding body often initiates PFINs, they usually have a centralised hub responsible for building and managing the PFIN and the contributing organisations (Rampersad, Quester, \& Troshani, 2010; Uzzi, 1997). However, much of the innovation activities are planned and executed bottomup through the individual organisations requiring self-governance by the participating organisations, similar to de-centralised innovation networks (L. Aarikka-Stenroos \& Sandberg, 2012).

This research investigates the following research question: How do interorganisational relationships of participating organisations affect performance in Publicly Funded Innovation Networks (PFINs)? We present in-depth insights from a longitudinal, embedded case study of a PFIN in the Nordic maritime industry, based on rich data from both quantitative and qualitative data collection. Our findings show three emerging patterns of inter-organisational relationships (functional, dysfunctional, and anarchic). Our findings further show the contribution of these three patterns of inter-organisational relationships to performance in the PFIN in terms of specific performance factors including innovation capabilities and growth. This 
research contributes to the literature in the field by linking network performance to inter-organisational relationships and their evolution in the PFIN.

\section{Literature review}

PFINs are a type of innovation network that brings together a diverse set of private and public organisations to innovate collaboratively (Reypens et al., 2016).

Participating organisations include manufacturers, research institutes, universities, and consultancies. PFINs are funded and often initiated by a public funding body, such as national government funds or the European Commission and often aim at achieving long-term societal benefits, such as economic growth (Cano-Kollmann, Hamilton, \& Mudambi, 2016; Scandura, 2016). For example, Horizon 2020 aims to fund various innovation activities that address societal challenges related to, for example environmental or social sustainability. However, the objectives of participating organisations can be more immediate in nature as companies may aim to develop new technologies to explore new market opportunities (Larsson, Bengtsson, Henriksson, \& Sparks, 1998; Michaelides, Morton, \& Liu, 2013). Participating partners benefit from resource interactions with other partners (Eklinder-Frick \& Åge, 2017), with often longterm and stable business exchange (Leena Aarikka-Stenroos \& Ritala, 2017). However, PFINs also have potential risk including unintended knowledge spill-overs, free-riders (Planko et al., 2017), and potentially competing priorities between contributing organisations (Ford, Verreynne, \& Steen, 2018). As a result, PFINs have also been criticised regarding their effectiveness and efficiency of reaching performance outcomes (Cumming \& Fischer, 2012; Link \& Wright, 2015; Spanos \& Vonortas, 2012). In summary, the nature of the inter-organisational relationships between the different participating organisations within a PFIN have potential effects on the performance. 
These observations align with argumentation of contingency theory (CT) (Lawrence \& Lorsch, 1967) combined with information-processing theory (IPT) (Galbraith, 1974). CT states that organisations may need to collaborate with relevant suppliers and customers to achieve the desired output (Lawrence \& Lorsch, 1967). IPT states that organisations achieve performance by accessing information of appropriate richness for the task (Bonner, 2010; Heim \& Mallick, 2012) eluding to the need for closeness in the inter-organisational relationships to enable successful innovation. Hence, in combination, these two theories enable us to study the link between interorganisational relationships in networks as a key determinant of performance gains (Bonner, 2010; M.E. Kreye, 2017; Wong, Lai, Cheng, \& Lun, 2015). However, current research has focused on dyadic set-ups between a provider and their customer. Research on more complex network-type settings and especially PFINs, where organisations of different nature, tradition and process-structure interact is relatively immature. This is a gap this research aims to address.

\subsection{Inter-organisational relationships in PFINs}

Inter-organisational relationships define the social routines and behaviours which are utilised to effectively create, exchange and exploit knowledge and skills (Brink, 2018) and thus include both formal as well as informal linkages between partners (Melanie $\mathrm{E}$. Kreye, Roehrich, \& Lewis, 2015). Formally, inter-organisational relationships are determined by the PFIN structure where the structural positions of firms and actors determine their interactions with other organisations and the nature of collaboration (Buchmann \& Pyka, 2015). Here, network administration has an important role because of their power to influence activities in the network (Nordin et al., 2018; Uzzi, 1997). Power is defined as the "ability to influence the decisions or actions of others" 
(Thorelli, 1986, p. 38) and network administration can enforce processes and guidelines throughout the evolution of the network to contribution of each individual participating organisation (Sydow \& Windeler, 1998). Network administration typically also has decision making power in terms of punishing lack of contribution or exclusion of an organisation from the innovation network (Sturgeon, Biesebroeck, \& Gereffi, 2008). PFINs thus contain many formal characteristics, including enforcements by central network administration which provides the formal framework for the collaboration in the PFIN.

Inter-organisational relationships in PFINs are also characterised by more informal processes, which are determined by the actions of the participating organisations. Informal processes enable the sharing of rich information (Daft, Lengel, \& Trevino, 1987). Factors such as the quality of collaboration in terms of knowledge sharing (Cano-Kollmann et al., 2016; Cumming \& Fischer, 2012; M.E. Kreye, 2017; Toole, 2012), the perception of shared goals (L. Aarikka-Stenroos \& Sandberg, 2012; Weick, 1979), and contribution to the network goals (Matinheikki, Pesonen, Artto, \& Peltokorpi, 2017) affect how relationships form and evolve throughout the PFIN. Openness, reciprocity and non-contractual contributions symbolise the intentions of partnering organisations and commitment to the network (M.E. Kreye, 2017; Uzzi, 1997) and enable performance. Specifically, individual employees form central instruments for achieving well-functioning inter-organisational relationships (Leena Aarikka-Stenroos, Jaakkola, Harrison, \& Mäkitalo-Keinonen, 2017; HurmelinnaLaukkanen \& Nätti, 2018; Melanie E. Kreye, 2018), creating complex social interactions. These interactions have been highlighted to enable the achievement of innovation goals (Kalsaas, 2013; Matinheikki et al., 2017) by creating knowledge- 
related effects (Buchmann \& Pyka, 2015) including the exchange of tacit and proprietary know-how (Hofman, Halman, \& Song, 2017). In addition, interorganisational relationships develop over time as the network evolves (Buchmann \& Pyka, 2015). PFINs are thus also characterised by informal processes of interorganisational relationships and their evolution over time. Table 1 summarises the characteristics of inter-organisational relationships in PFINs.

\section{<Please insert Table 1 about here>}

Inter-organisational relationships are core to achieving performance outputs in PFINs (Dolfsma \& Van der Eijk, 2016; Jarillo, 1988; Kalsaas, 2013; Matinheikki et al., 2017). While innovation networks in general can be either centrally administered via formal frameworks for the innovation activities and collaboration (Buchmann \& Pyka, 2015) or self-governed via social interactions that are characterised by informal processes (L. Aarikka-Stenroos \& Sandberg, 2012), PFINs typically constitute a hybrid form between the two where the inter-organisational relationships are affected by the alignment between formal and informal nature of activities and processes (Bechky, 2006). Here, alignment refers to the level of agreement between network administration and participants regarding the factors described in Table 1.

\subsection{Performance in PFINs}

PFINs are credited with targeting and often achieving various performance benefits based on the wide range of activities and type of participating organisations (CanoKollmann et al., 2016; Cumming \& Fischer, 2012; Matinheikki et al., 2017). Here, the achievement of innovation goals of the specific PFIN have been highlighted (Matinheikki et al., 2017) as well as other performance benefits for the participating firms and industry and society in general, including innovation capabilities, growth and 
network capabilities (Bozeman \& Youtie, 2017; Scandura, 2016). One of the most frequently described performance factor is economic growth (Cumming \& Fischer, 2012; Maroto, Gallego, \& Rubalcaba, 2016). This includes on the one hand financial benefits for the participating organisations through finances provided to and by the PFIN as well as the improved efficiency of innovation activities (Maroto et al., 2016). This also includes economic growth through increased sales of participating firms (Cumming \& Fischer, 2012) and related growth in the wider industry sector.

Furthermore, PFINs can create immediate positive effects in terms of innovation capabilities (Scandura, 2016). Here, the organisational structure within the PFIN via centralised network administration and administration can give important support for fostering innovation (Cano-Kollmann et al., 2016). Research has found that the participation in a PFIN increases innovation activities, such as market release of new products (Toole, 2012) or patents (Cumming \& Fischer, 2012). This includes improved technological capabilities of the participating organisations (Huergo \& Moreno, 2017).

PFINs are also described to create non-economic social outcomes, such as improved network capabilities (Bozeman \& Youtie, 2017). Research has found a positive effect of PFIN participation on openness of innovation practices that include collaboration with external partners in future innovation activities (Cano-Kollmann et al., 2016). As a result, the participation in a PFIN in turn increases the formation of alliances for the participating organisation (Cumming \& Fischer, 2012) and thus improves the overall network within the industry sector. Table 2 summarises the key performance factors of PFINs described in the literature.

<Please insert Table 2 about here 


\subsection{Conceptual framework}

We investigate our research question through a conceptual framework. Based on a combination of CT (Lawrence \& Lorsch, 1967) and IPT (Galbraith, 1974), we investigate how the nature of the inter-organisational relationships affect the achievement of PFIN performance (Figure 1). These inter-organisational relationships are developed over time as partner selection during network formation set the overall framework for the collaboration between specific partners which then evolves further as objectives are being fulfilled. Specifically, the different nature of these participating organisations - spanning firms of different types, governmental bodies and public organisations may affect the effectiveness of collaboration and coordination activities. We investigate the inter-organisational relationships in PFINs in terms of the level of alignment between network administration and the nature of collaboration and coordination between participating organisations. The combination of the formally imposed network structure determined by central network administration (Buchmann \& Pyka, 2015) and the informally formed relationships between participating organisations (L. AarikkaStenroos \& Sandberg, 2012) may create challenges within the PFIN.

\section{<Please include Figure 1 about here>}

Further, we investigate PFIN performance as a diverse set of performance factors including innovation capabilities (Cano-Kollmann et al., 2016; Scandura, 2016), network capabilities (Bozeman \& Youtie, 2017), economic growth (Cumming \& Fischer, 2012; Maroto et al., 2016), and the achievement of potentially other network goals (Matinheikki et al., 2017). The purpose of this research is to identify the link between these concepts of inter-organisational relationships and network performance. Our conceptual framework details the elements of these concepts and we aim to identify 
links between them.

\section{Method}

Due to the exploratory nature of this research, we employ a qualitative research approach via a single, longitudinal case study (Beverland \& Lindgreen, 2010). Longitudinal case studies are particularly relevant to collect the in-depth insights of factors determining performance in innovation networks and has also been used in recent literature in the field (Brink, 2018; Nordin et al., 2018). The presented case is based on unique data access to a PFIN in the maritime industry, which could be studied in its entirety from start to end (Eisenhardt, 1989). This offered rich insights into the dynamics within the network to answer the research question (Yin, 2018).

\subsection{Case selection}

The case PFIN was set in the maritime industry and was sponsored by a Scandinavian government. The recent pressures on reducing environmental impact and improve innovativeness of the whole sector (Perunovic, Christoffersen, \& Fürstenberg, 2015) created an increase in governmental regulation and investment in innovation activities in this industry sector. The case PFIN was thus suitable for the purpose of this research as it aligns with characterisations of PFINs described in the literature (Eklinder-Frick \& Åge, 2017; Reypens et al., 2016). The case PFIN aimed at the development of a new range of products and solutions to address the international environmental regulations. The case PFIN consisted of 15 independent projects, 14 of which were part of the initial network formation. The $15^{\text {th }}$ project was added during the operation phase, as funds were available for the additional innovation. In total, 38 organisations participated in the case PFIN from a range of diverse backgrounds including equipment 
manufacturers (EMs), customers (Owners), consultants, designers, and universities in line with descriptions in the literature (Leena Aarikka-Stenroos et al., 2014; Planko et al., 2017). Table 3 briefly describes the individual organisations and their participation in the case PFIN.

\section{<Please include Table 3 about here>}

This research applied an embedded design describing the network-level performance in connection to the inter-organisational relationships on project level. PFIN performance was assessed on network level, analysing the overall achievement of performance factors over the duration of the PFIN. Inter-organisational relationships were analysed on project-level within the PFIN (15 separate projects as described above) to identify specific dynamics between the partners. This embedded design enables to gain in-depth understanding of the empirical setting and dynamics in terms of the researched concepts to generate rich and reliable research models (Eisenhardt, 1989).

\subsection{Data collection}

The empirical data were gathered longitudinally to investigate the evolution of the case PFIN including performance-affecting developments. The case PFIN was studied throughout its existence as an innovation network (2014-2019). Data collection included meetings with network administration, observation of network steering workshops and meetings, semi-structured interviews with participating organisations, surveys, and secondary data. The individual data collection method followed the specific rules of rigour was the most suitable approach to data collection was chosen at different times during the longitudinal set-up to best satisfy the purpose of the specific point in time. For example, the nature of partner selection and network 
formation was studied via qualitative semi-structured interviews (in 2014) while the network goals were triangulated between formation documentation and interviews with the network manager. In combination the different data sources enabled triangulation of the findings (Yin, 2018). Table 4 depicts the data collection methods applied to the specific PFIN projects.

\section{<Please include Table 4 about here>}

Performance data was collected via a survey of all participating organisations (65 in total) of which we received 52 complete responses. This was deemed the most suitable approach because it limits the potential biasing effect of the researchers on the participants while offering a broad and rich set of data spanning the whole case PFIN (Creswell, 2014). The respondents were asked to evaluate the achievement of the performance factors from our conceptual framework on a 5-point likert scale ("strongly disagree" - 1 to "strongly agree" - 5). A further survey was collected during the start-up phase of the case PFIN to investigate the nature of the inter-organisational relationships. Here, we received 44 complete responses (of the 60 project participants at that stage of the case PFIN). Furthermore, qualitative data was collected in the form of semi-structured interviews with the network manager, project managers and project participants as well as unstructured observations of network meetings and workshops. These interviews were guided by a questionnaire focusing on the nature of the inter-organisational relationships as defined in our conceptual framework. This combination of data collection methods resulted in an in-depth and detailed understanding of the case PFIN and performance related influence.

\subsection{Data analysis}

The unit of analysis is the innovation network, i.e. the PFIN. The analysis of the data 
sources was undertaken iteratively to achieve a rigorous and detailed account of the case PFIN (Miles, Huberman, \& Saldaña, 2014). In a first step, each of the individual data sources (surveys, interviews, observations etc.) was analysed individually. This involved relevant analysis methods including qualitative approaches (via iterative coding of the interview transcripts, observation notes and secondary data sources) and quantitative data analysis approaches (via statistical analysis). The qualitative analysis followed an abductive approach (Dubois \& Gadde, 2002) starting with the conceptual framework before coding the data in an more emergent approach based on the researchers' understanding of the case. This resulted in the identification of relationship patterns (detailed in Section 4.1) based on the level of alignment between network administration and participating organisations. The quantitative data analysis utilised simple statistics tools such as descriptive statistics to derive insights regarding the PFIN performance. This aligns with the small sample size of our survey responses. This was based on a translation of the structured quantitative survey responses to numerical values ( 1 - strongly disagree to 5 - strongly agree with given statement), aligned with typical approaches likert-scales (Robson, 2011). In a second step, the data sources were combined using triangulation to validate initial insights and increase reliability of our conclusions and provide broader insights of the observed phenomena (Yin, 2018). This enabled us to derive meaningful insights from the empirical data relevant for the inductive nature of this research (Eisenhardt, 1989).

\section{Findings}

The case PFIN was initiated by the national maritime industry body and aimed at enhancing growth in the maritime industry and improving environmental sustainability by reducing emissions. They understood the need for different organisations in the 
industry to collaborate in order to achieve the ambitious PFIN objectives: "The industry is complex and diversified and cooperation between the different parties could be more efficient. In that sense, the [case PFIN] is an investment in the development of a strong common innovation model that will offer a central, competitive advantage for the Danish maritime industry" (PFIN funding application). Table 5 details the specific PFIN objectives outlined in the funding application as well as highlighted in the different interviews and observations. The case PFIN was the first centrally organised innovation network on this scale aimed at facilitating the long-term development of an innovative and internationally competitive industry sector.

\section{<Please insert Table 5 about here>}

\subsection{Inter-organisational relationships}

The inter-organisational relationships between the participating organisations differed between the projects. Three patterns of inter-organisational relationships emerged from the data analysis depending on the level of alignment between network administration and links between the participating organisations. The first pattern focused on projects where the participating organisations' partnering decisions were well aligned with the network and network administration. Here, inter-organisational relationships formed bottom up as Project owner and manager (Project 1) explained: "You would try to sell the project for the other participants. And rather soon, there were four that were interested [in our project]." The project goals and partnerships complied with network administration resulting in positive and constructive relationships as exemplified by project owner and manager of Project 1 (EM1): "we all pull in the same direction." Other projects in this pattern were Projects $7,10,12$, and 13. Project owner and manager of Project 10 concluded: "I think everybody is quite 
happy." Thus, the first pattern showed functional inter-organisational relationships.

The second pattern, in contrast, focused on projects where participating organisations' partnering decisions and network administration directives were misaligned. Here, initial inter-organisational relationships also formed bottom up but network administration then interfered. One example was Project 14 where already in the creation of the partnership, many difficulties arose as Project participant of Project 14 explained: "There was actual discussion whether they should pull the break and leave this entire project out of the proposal. But for some reason, they decided to keep it. And I think there was pressure (...) So that was a political decision." In the end, the project was kept in the case PFIN and the final partners had to find a way of working with each other. One interesting observation here was the formation of functional subcircles of inter-organisational relationships within the projects where specific activities were completed independently from each other with minimal (if none at all) collaboration. Consultant 6 (Project 4) explained this as follows: "because [Research2] is a competitor (...) So we ended up having a project where we have what we call open room and closed room." Research 2 mirrored this assessment as follows: "In our contract, we had to define something that we call open room and closed room which means that they are doing a lot of things in closed rooms so we are not even invited. And a lot of information is lost, of course." Thus, the second pattern showed dysfunctional inter-organisational relationships where the partnering choices of participating organisations and network administration were misaligned, with the potential effect of creating functional networks within the network to overcome the limitations of these dysfunctional relationships. 
The third pattern, concerned projects that lacked clear goals for the interorganisational relationships because of lacking project leadership. The relationships also formed bottom-up (similar to Patterns 1 and 2 above), however, none of the partners took leadership of the project activities. Similarly, network administration did not enforce project leadership. As a result, the project partners completed their immediate project tasks but did not achieve collaboration potentials. Project manager of Project 9 exemplified this with regard to knowledge sharing between the partners: "We have made a share-point side. I must say that we have not used it so much." We termed this third pattern as anarchical because these relationships predominantly consisted of bottom-up organisational participation choices but lacked clear leadership.

\subsection{Performance}

Table 6 shows the performance of the case PFIN with regard to the performance factors detailed in our conceptual framework, and the achievement of network goals, such as efficiency, growth, emission reduction, and dissemination for each of the projects. On a general level, the survey assessment of the performance levels were moderate with values rarely exceeding 4 points on the 5 -point likert scale. This may be due to the long-term nature if the PFIN goals concerning the future of the maritime industry as a whole. Overarching trends for the case PFIN include the overall improved efficiency (average of 3.8 out of 5) and network capabilities (average of 3.4 out of 5) of participating companies. Furthermore, specifically manufacturers benefitted from the case PFIN in terms of patent applications receiving 9 of the 11 patent applications from the case PFIN. Finally, the case PFIN had low effects on growth (average of 2.7 out of 5) and emission reduction (average of 2.4 out of 5). 


\subsection{Linking inter-organisational relationships to performance}

Table 7 shows the network performance factors linked to the three patterns of interorganisational relationships. The analysis shows surprising insights specifically with regard to two of the observed relationship patters: functional and dysfunctional relationships. Our results indicate that functional relationships received most immediate benefits of the case PFIN in terms of jobs created (more than double than the other two patterns) and patent applications (solely in Pattern 1). This suggests that those projects whose goals aligned well aligned with network goals received most direct benefits from participating in the case PFIN. Our findings also indicate that functional relationships (Pattern 1) had highest performance with regard to network capabilities, especially with existing partners. However, this pattern also showed lowest values for the difference the case PFIN made to their network overall. These suggests that functional relationships enabled the participating organisations to deepen their connections with existing partners only, an outcome they could have achieved with other means that a PFIN according to the participating organisation's own evaluations. Finally, functional relationships (Pattern 1) also showed highest performance in terms of efficiency. This suggests that the participating organisations in these projects could have done the innovation projects without the case PFIN; however, participating in the case PFIN enabled them to achieve the outcomes faster and cheaper.

\section{<Please insert Table 7 about here>}

Our results indicate that dysfunctional inter-organisational relationships (Pattern 2) 
had highest performance with regard to long-term performance factors including innovation capabilities, specifically regarding the development of new products, new services and the creation of start-up firms. This suggests that dysfunctional relationships in PFINs perform better with regard to innovation goals than functional relationships.

\section{Discussion and conclusions}

\subsection{Key research insights}

This research presented insights from a case PFIN, which had overall relatively low performance values fuelling the criticism into effectiveness and efficiency of these types of innovation networks (Cumming \& Fischer, 2012; Link \& Wright, 2015; Spanos \& Vonortas, 2012). Using a conceptual lens based on Contingency Theory (Lawrence \& Lorsch, 1967) and Information-Processing Theory (Galbraith, 1974), our findings showed two key research insights. First, we identified three patterns of interorganisational relationships during network evolution, which were a direct result of the PFIN characteristics. Here, we showed the existence of functional, dysfunctional and anarchical inter-organisational relationships. Second, we identified the effects of these patterns of inter-organisational relationships on performance, revealing some counter-intuitive effects. Specifically, we showed that functional relationships enabled the achievement of more immediate performance effects, while dysfunctional relationships had more long-term potential. We distil these insights into a refined conceptual framework of the performance effects of inter-organisational relationships. In this section, we discuss these insights and their contribution to the literature and aim to distil clear implications for network administration. 
The first key insight concerns the three observed patterns of interorganisational relationships in the case PFIN. These patterns were direct consequences of the unique characteristics of PFINs as hybrid forms of organisation, combining formal centralised network administration with informal de-centralised activities. Our findings revealed the following three patterns: functional relationships (alignment between the self-organised relationships by project partners and relationship requirements from network administration), dysfunctional relationships (contradictions between the self-organised relationships by project partners and relationship requirements from network administration), and anarchic relationships (self-organised relationships by project partners with a lack of direction or leadership). While the individual nature of these three patterns of inter-organisational relationships has been described in the literature before (Leena Aarikka-Stenroos et al., 2017; Melanie E. Kreye, 2017), their simultaneous co-existence within one PFIN (and thus the same network administration) is new to the literature. Our research thus contributes by showing the specifics of three patterns of inter-organisational relationships as they evolve within the PFIN, resulting from the hybrid nature of PFINs. The second key insight concerns the effect these three patterns of interorganisational relationships have on the performance in the PFIN. Our findings suggest that functional relationships are related to higher immediate performance effects such as patent applications, job creation, and deeper relationships to existing partners. In contrast and arguably counterintuitively, dysfunctional relationships were linked to higher performance effects with potentially long-term value generation including improving innovation capabilities, new service-based business models and network capabilities overall. This is a surprising insight because the literature suggests that it 
should be functional relationships that create highest performance in innovation networks (La Rocca \& Snehota, 2014; Medlin \& Törnroos, 2015; Nordin et al., 2018).

Our findings can be explained by the way the project partners organised the innovation capabilities. Designed to evade the pressures from network administration regarding partner choice, they created sub-circles of functional relationships that enabled them to achieve their innovation goals even superseding projects with functional relationships (only). These observations contrast our findings of functional relationships where largest effects of network capabilities, efficiency, and growth (job creation) were achieved. In other words, the participating organisations created subcircles of functioning relationships within dysfunctional relationships (nested networks) to circumvent the potentially threatening effects of misalignment between partner objectives and central network management. IN this process, however, they also undermined the achievement of PFIN goals, including the improvement of the industry network in general. Our research thus shows the performance-relevant effects of the three observed patterns of inter-organisational relationships in PFINs and points towards behaviour evasion mechanisms to avoid negative effects of political pressure.

Based on these key insights, we propose a conceptual framework that details the potential performance effects of the inter-organisational relationships within the PFIN and hence answers the research question posed at the outset of this work. Figure 2 depicts the proposed conceptual framework and shows the varying levels of performance effects based on the nature of the inter-organisational relationships in the form of the three observed patterns. We use a grey arrow linking the two depicted boxes to indicate the overall performance effects of participating in the PFIN. Our 
research suggests additional performance effects of particularly functional and dysfunctional relationships. Functional relationships create specifically positive immediate performance effects such as patent applications (part of innovation capabilities), job creation (part of growth) and a deeper relationships with existing partners. In contrast, dysfunctional relationship create positive long-term effects with the possibility of achieving long-term change within a business environment, including (more general) innovation capabilities, networking capabilities, and the creation of new business models.

\section{<Please insert Figure 2 about here>}

\subsection{Practical implications}

Our research has important implications for practice, responding to the overall concerns regarding the effectiveness and efficiency of many PFINs. Specifically, we can distil implications for network administration and policy making from the research presented in this paper. Our research shows the central importance of interorganisational relationships in determining performance in PFINs. Thus, network managers need to carefully administer these inter-organisational relationships throughout the evolution of the PFIN. Specifically, network administration should align central objectives with regard to participating organisation with the de-centralised relationships formed in network formation. Our research showed that depending on the pressures from central network administration, the inter-organisational relationships that developed based on the preferences from participating organisations resulted either in functional relationships or in dysfunctional relationships characterised by sub-circles of collaboration. These observations could have been avoided if central network administration had shown more nuanced 
considerations for de-centralised partner choices or if it had managed the integration of centrally enforced partners more carefully. Network managers are thus advised to carefully consider their decisions regarding the choice of partners within the PFIN and specifically implement these decisions throughout the evolution of the PFIN.

Our research further has important implications for policy makers. Using these innovation networks as policy implementation tools, PFINs are required to yield the target performance results. Our research showed that the conservative approach to innovation objectives (development projects of known technological value) and choice of participating organisations (the existing "big players" in the industry sector) can reduce the positive performance effects of PFINs with regard to innovation capabilities and network capabilities. Policy makers thus need carefully consider their approach to PFINs in terms of powers given to network administration to be able to achieve the target performance outcomes.

\subsection{Limitations and future research}

Limitations apply to this research. Case study research is sometimes criticised for observer bias and subjectivity in interpreting the findings (Yin, 2018). We mitigated these insights by utilising multiple sources of evidence that enabled us to triangulate qualitative and quantitative data and ensure rigour in the presented findings (Gibbert

\& Ruigrok, 2010). Furthermore, the presented case study focused on the Nordic maritime industry and the presented results are thus to be seen as embedded within the specific context and dynamics of this industry sector (Barratt, Choi, \& Li, 2011). Our research thus only has limited applicability to PFINs set in other industry sector and policy situations. 
Further cases including additional industrial sectors need to be investigated to complement this research and help further theory building in PFIN management and inter-organisational relationships. This will improve generalisability of our insights. Further work also needs to be done on the link between the level of innovativeness of the initiatives within a PFIN and the overall performance in terms of improving innovation capabilities as well as network capabilities. Our research indicates that there could be a positive connection between both factors and further research on this link would have strong contributions to the literature and practice in the field. Finally, one emerging finding of our study was the creation of sub-circles or nested networks to enable free communication in politically enforced network projects. This findings deserves further research to investigate the behavioural antecedents as well as wider (industry level) consequences.

\section{References}

Aarikka-Stenroos, L., \& Sandberg, B. (2012). From new-product development to commercialization through networks. Journal of Business Research, 65(2), 198206.

Aarikka-Stenroos, Leena, Jaakkola, E., Harrison, D., \& Mäkitalo-Keinonen, T. (2017). How to manage innovation processes in extensive networks: A longitudinal study. Industrial Marketing Management, 67, 88-105. https://doi.org/10.1016/j.indmarman.2017.09.014

Aarikka-Stenroos, Leena, \& Ritala, P. (2017). Network management in the era of ecosystems: Systematic review and management framework. Industrial Marketing Management, 67(September), 23-36. https://doi.org/10.1016/j.indmarman.2017.08.010

Aarikka-Stenroos, Leena, Sandberg, B., \& Lehtimäki, T. (2014). Networks for the commercialization of innovations: A review of how divergent network actors contribute. Industrial Marketing Management, 43(3), 365-381. 
https://doi.org/10.1016/j.indmarman.2013.12.005

Barratt, M., Choi, T. Y., \& Li, M. (2011). Qualitative case studies in operations management: Trends, research outcomes, and future research implications. Journal of Operations Management, 29(4), 329-342. https://doi.org/http://dx.doi.org/10.1016/j.jom.2010.06.002

Bechky, B. A. (2006). Gaffers, Gofers, and Grips: Role-Based Coordination in Temporary Organizations. Organization Science, 17(1), 3-21. https://doi.org/10.1287/orsc.1050.0149

Beverland, M., \& Lindgreen, A. (2010). What makes a good case study? A positivist review of qualitative case research published in Industrial Marketing Management, 1971-2006. Industrial Marketing Management, 39(1), 56-63. https://doi.org/10.1016/j.indmarman.2008.09.005

Bonner, J. M. (2010). Customer interactivity and new product performance: Moderating effects of product newness and product embeddedness. Industrial Marketing Management, 39(3), 485-492. https://doi.org/10.1016/j.indmarman.2008.11.006

Bozeman, B., \& Youtie, J. (2017). Socio-economic impacts and public value of government-funded research: Lessons from four US National Science Foundation initiatives. Research Policy, 46(8), 1387-1398. https://doi.org/10.1016/j.respol.2017.06.003

Brink, T. (2018). Organising of dynamic proximities enables robustness, innovation and growth: The longitudinal case of small and medium-sized enterprises (SMEs) in food producing firm networks. Industrial Marketing Management, 75(June 2017), 66-79. https://doi.org/10.1016/j.indmarman.2018.04.005

Buchmann, T., \& Pyka, A. (2015). The evolution of innovation networks: the case of a publicly funded German automotive network. Economics of Innovation and New Technology, 24(1-2), 114-139. https://doi.org/10.1080/10438599.2014.897860

Cano-Kollmann, M., Hamilton, R. D., \& Mudambi, R. (2016). Public support for innovation and the openness of firms' innovation activities. Industrial and Corporate Change, 26(3), 421-442. https://doi.org/10.1093/icc/dtw025 
Creswell, J. W. (2014). Research design: Qualitative, quantitative, and mixed methods approaches (4th ed.). Thousand Oaks, CA, USA: Sage.

Cumming, D. J., \& Fischer, E. (2012). Publicly funded business advisory services and entrepreneurial outcomes. Research Policy, 41(2), 467-481. https://doi.org/10.1016/j.respol.2011.09.004

Daft, R. L., Lengel, R. H., \& Trevino, L. K. (1987). Message Equivocality, Media Selection, and Manager Performance: Implications for Information Systems. MIS Quarterly, 11(3), 355-366. https://doi.org/10.2307/248682

Dolfsma, W., \& Van der Eijk, R. (2016). Network position and firm performance-the mediating role of innovation. Technology Analysis \& Strategic Management, 29(6), 1-13. https://doi.org/10.1080/09537325.2016.1216095

Dubois, A., \& Gadde, L. E. (2002). Systematic combining: An abductive approach to case research. Journal of Business Research, 55(7), 553-560.

Eisenhardt, K. M. (1989). Building theories from case study research. Academy of Management Review, 14(4), 532-550.

Eklinder-Frick, J., \& Åge, L. J. (2017). Perspectives on regional innovation policy - From new economic geography towards the IMP approach. Industrial Marketing Management, 61, 81-92. https://doi.org/10.1016/j.indmarman.2016.07.005

Ford, J. A., Verreynne, M. L., \& Steen, J. (2018). Limits to networking capabilities: Relationship trade-offs and innovation. Industrial Marketing Management, 74(July 2017), 50-64. https://doi.org/10.1016/j.indmarman.2017.09.022

Galbraith, J. R. (1974). Organization Design: An Information Processing View. Interfaces, 4(3), 28-36. https://doi.org/10.1287/inte.4.3.28

Gibbert, M., \& Ruigrok, W. (2010). The "What" and "How" of Case Study Rigor: Three Strategies Based on Published Work. Organizational Research Methods, 13(4), 710-737. https://doi.org/10.1177/1094428109351319

Giovannetti, E., \& Piga, C. A. (2017). The contrasting effects of active and passive cooperation on innovation and productivity: Evidence from British local innovation networks. International Journal of Production Economics, 187(February), 102-112. https://doi.org/10.1016/j.ijpe.2017.02.013 
Heim, G. R., \& Mallick, D. N. (2012). Antecedents and Consequences of New Product Development Practices and Software Tools: An Exploratory Study. IEEE Transactions on Engineering Management, 59(3), 428-442. https://doi.org/10.1109/TEM.2011.2172608

Hofman, E., Halman, J. I. M., \& Song, M. (2017). When to Use Loose or Tight Alliance Networks for Innovation? Empirical Evidence. Journal of Product Innovation Management, 34(1), 81-100. https://doi.org/10.1111/jpim.12325

Huergo, E., \& Moreno, L. (2017). Subsidies or loans? Evaluating the impact of R\&D support programmes. Research Policy, 46(7), 1198-1214. https://doi.org/10.1016/j.respol.2017.05.006

Hurmelinna-Laukkanen, P., \& Nätti, S. (2018). Orchestrator types, roles and capabilities - A framework for innovation networks. Industrial Marketing Management, 74(September 2017), 65-78. https://doi.org/10.1016/j.indmarman.2017.09.020 Jarillo, J. C. (1988). On strategic networks. Strategic Management Journal, 9, 31-41. Jenssen, J. I., \& Rand øy, T. (2006). The performance effect of innovation in shipping companies. Maritime Policy and Management, 33(4), 327-343.

Kalsaas, B. T. (2013). Collaborative innovation: The decade that radically changed drilling performance. Production Planning and Control, 24(2-3), 265-275. https://doi.org/10.1080/09537287.2011.647881

Kreye, M.E. (2017). Relational uncertainty in service dyads. International Journal of Operations \& Production Management, 37(3), 363-381.

Kreye, Melanie E. (2017). Can you put too much on your plate? Uncertainty exposure in servitized triads. International Journal of Operations \& Production Management, 37(12), 1722-1740. https://doi.org/10.1108/IJOPM-06-2016-0357

Kreye, Melanie E. (2018). Interactions between perceived uncertainty types in service dyads. Industrial Marketing Management, 75, 90-99. https://doi.org/10.1016/j.indmarman.2018.04.014

Kreye, Melanie E., Roehrich, J. K., \& Lewis, M. A. (2015). Servitising manufacturers: the impact of service complexity and contractual and relational capabilities. Production Planning \& Control, 26(14), 1233-1246. 
https://doi.org/10.1080/09537287.2015.1033489

La Rocca, A., \& Snehota, I. (2014). Relating in business networks: Innovation in practice. Industrial Marketing Management, 43(3), 441-447. https://doi.org/10.1016/j.indmarman.2013.12.012

Larsson, R., Bengtsson, L., Henriksson, K., \& Sparks, J. (1998). The Interorganizational Learning Dilemma: Collective Knowledge Development in Strategic Alliances. Organization Science, 9(3), 285-305.

Lawrence, P., \& Lorsch, J. W. (1967). Organization and Environment: Managing Differentiation and Integration. Cambridge, MA, USA: Harvard Business School Press.

Link, A. N., \& Wright, M. (2015). On the Failure of R\&D Projects. IEEE Transactions on Engineering Management, 62(4), 442-448.

https://doi.org/10.1109/TEM.2015.2404873

Maroto, A., Gallego, J., \& Rubalcaba, L. (2016). Publicly funded R \& D for public sector performance and efficiency : evidence from Europe. R\&D Management, 1-15. https://doi.org/10.1111/radm.12215

Matinheikki, J., Pesonen, T., Artto, K., \& Peltokorpi, A. (2017). New value creation in business networks: The role of collective action in constructing system-level goals. Industrial Marketing Management, 67(June), 122-133. https://doi.org/10.1016/j.indmarman.2017.06.011

Medlin, C. J., \& Törnroos, J. Å. (2015). Exploring and exploiting network relationships to commercialize technology: A biofuel case. Industrial Marketing Management, 49, 42-52. https://doi.org/10.1016/j.indmarman.2015.05.036

Michaelides, R., Morton, S. C., \& Liu, W. (2013). A framework for evaluating the benefits of collaborative technologies in engineering innovation networks. Production Planning and Control, 24(2-3), 246-264. https://doi.org/10.1080/09537287.2011.647880

Miles, M. B., Huberman, A. M., \& Saldaña, J. (2014). Qualitative Data Analysis: A Methods Sourcebook (3rd ed.). Thousand Oaks, CA, USA: Sage Publications, Inc. Nordin, F., Ravald, A., Möller, K., \& Mohr, J. J. (2018). Network management in 
emergent high-tech business contexts: Critical capabilities and activities. Industrial Marketing Management, 74(September 2017), 89-101.

https://doi.org/10.1016/j.indmarman.2017.09.024

Perunovic, Z., Christoffersen, M., \& Fürstenberg, S. (2015). Unleashing the potential of maritime innovation networks. Copenhagen, Denmark.

Planko, J., Chappin, M. M. H., Cramer, J. M., \& Hekkert, M. P. (2017). Managing strategic system-building networks in emerging business fields: A case study of the Dutch smart grid sector. Industrial Marketing Management, 67(June), 37-51. https://doi.org/10.1016/j.indmarman.2017.06.010

Rampersad, G., Quester, P., \& Troshani, I. (2010). Managing innovation networks: Exploratory evidence from ICT, biotechnology and nanotechnology networks. Industrial Marketing Management, 39(5), 793-805. https://doi.org/10.1016/j.indmarman.2009.07.002

Reypens, C., Lievens, A., \& Blazevic, V. (2016). Leveraging value in multi-stakeholder innovation networks: A process framework for value co-creation and capture. Industrial Marketing Management, 56, 40-50. https://doi.org/10.1016/j.indmarman.2016.03.005

Ritter, T., \& Gemünden, H. G. (2003). Network competence: Its impact on innovation success and its antecedents. Journal of Business Research, 56(9), 745-755. https://doi.org/10.1016/S0148-2963(01)00259-4

Robson, C. (2011). Real World Research - A Resource for Users of Social Research Methods in Applied Settings (3rd ed.). Chichesteer, UK: John Wiley \& Sons Ltd. Scandura, A. (2016). University-industry collaboration and firms' R\&D effort. Research Policy, 45(9), 1907-1922. https://doi.org/10.1016/j.respol.2016.06.009

Song, W., Cao, J., \& Zheng, M. (2016). Towards an integrative framework of innovation network for new product development project. Production Planning \& Control, 27(12), 967-978. https://doi.org/10.1080/09537287.2016.1167980

Spanos, Y. E., \& Vonortas, N. S. (2012). Scale and performance in publicly funded collaborative research and development. R\&D Management, 42(5), 494-513. https://doi.org/10.1111/j.1467-9310.2012.00698.x 
Sturgeon, T., Biesebroeck, J. Van, \& Gereffi, G. (2008). Value chains, networks and clusters: Reframing the global automotive industry. Journal of Economic Geography, 1-25. https://doi.org/10.1093/jeg/lbn007

Sydow, J., \& Windeler, A. (1998). Organizing and Evaluating Interfirm Networks: A Structurationist Perspective on Network Processes and Effectiveness. Organization Science, 9(3), 265-284.

Thorelli, H. B. (1986). Networks: Between Markets and Hierachies. Strategic Management Journal, 7(1), 37-51.

Toole, A. A. (2012). The impact of public basic research on industrial innovation: Evidence from the pharmaceutical industry. Research Policy, 41(1), 1-12. https://doi.org/10.1016/j.respol.2011.06.004

Uzzi, B. (1997). Social Structure and Competition in Interfirm Networks: The Paradox of Embeddedness. Administrative Science Quarterly, 42(1), 35-67. https://doi.org/10.2307/2393808

Weick, K. (1979). The Social Psychology of Organizing (2nd ed.). Reading, MA, USA: Addison-Wesley.

Wong, C. W. Y., Lai, K., Cheng, T. C. E., \& Lun, Y. H. V. (2015). The role of IT-enabled collaborative decision making in inter-organizational information integration to improve customer service performance. International Journal of Production Economics, 159(0), 56-65. https://doi.org/10.1016/j.ijpe.2014.02.019

Yin, R. K. (2018). Case study research and applications: Design and methods (6th ed.). Los Angeles, CA, USA: Sage Publications Inc. 


\section{Tables and Figures}

Table 1: Characteristics of inter-organisational relationships in PFINs

\begin{tabular}{|c|c|}
\hline Characteristic & Description \\
\hline PFIN structure & $\begin{array}{l}\text { Structural positions of firms and actors within the wider network determines their } \\
\text { interactions with other organisations including collaborative activities (Buchmann } \\
\text { \& Pyka, 2015) } \\
\text { Structure should follow the innovation process based on CT (Lawrence \& Lorsch, } \\
\text { 1967) } \\
\text { Network administration has power of influencing activities directly through } \\
\text { determining the PFIN structure and relative position of individual organisations } \\
\text { (Nordin et al., 2018; Uzzi, 1997). }\end{array}$ \\
\hline $\begin{array}{l}\text { Knowledge sharing } \\
\text { practices }\end{array}$ & $\begin{array}{l}\text { social routines and behaviour aimed at effectively creating, exchanging and } \\
\text { exploiting knowledge and skills (Giovannetti \& Piga, 2017; Melanie E. Kreye et al., } \\
\text { 2015) } \\
\text { exchange of rich information between partners as highlighted in IPT (Daft et al., } \\
\text { 1987) } \\
\text { creates trust through openness, reciprocity and non-contractual contributions } \\
\text { symbolising the intentions of partnering organisations and commitment (M.E. } \\
\text { Kreye, 2017; Uzzi, 1997) } \\
\text { shapes how inter-organisational relationships evolve over the duration of the } \\
\text { collaborations in the PFINs }\end{array}$ \\
\hline $\begin{array}{l}\text { Perception of } \\
\text { shared goals }\end{array}$ & $\begin{array}{l}\text { Overlap in motives and goals of the participation in the PFIN and the performed } \\
\text { activities in terms of timely delivery of agreed outputs (L. Aarikka-Stenroos \& } \\
\text { Sandberg, 2012) } \\
\text { Inter-organisational collaboration are usually directed towards a joint end goal } \\
\text { according to CT (Lawrence \& Lorsch, 1967) } \\
\text { Includes the contribution to network goals, i.e. the overarching aims of the whole } \\
\text { PFIN (Matinheikki et al., 2017) }\end{array}$ \\
\hline $\begin{array}{l}\text { Collaboration } \\
\text { through individual } \\
\text { employees } \\
\text { (boundary } \\
\text { spanners) }\end{array}$ & $\begin{array}{l}\text { complex social interactions between individuals create exchange of tacit and } \\
\text { proprietary know-how (Hofman et al., 2017) and hence enable the achievement of } \\
\text { innovation goals (Kalsaas, 2013; Matinheikki et al., 2017) } \\
\text { individuals' ability to process information determines organisational information- } \\
\text { processing capabilities (Galbraith, 1974) }\end{array}$ \\
\hline
\end{tabular}


Table 2: Performance factors of PFINs

\begin{tabular}{|l|l|}
\hline Performance factor & Description \\
\hline $\begin{array}{l}\text { Innovation } \\
\text { capabilities }\end{array}$ & $\begin{array}{l}\text { Improved innovation capabilities of participating organisations including } \\
\text { technological capabilities (Huergo \& Moreno, 2017) based on the innovation } \\
\text { activities in the PFIN and knowledge exchange with partners. } \\
\text { Measured in terms of market release of new products (Toole, 2012) or patents } \\
\text { (Cumming \& Fischer, 2012). }\end{array}$ \\
\hline $\begin{array}{l}\text { Network } \\
\text { capabilities }\end{array}$ & $\begin{array}{l}\text { Improved network structures within the industry sector (Bozeman \& Youtie, 2017) } \\
\text { including overall openness of innovation practices and collaboration with external } \\
\text { partners (Cano-Kollmann et al., 2016). } \\
\text { Measured in terms of new alliances formed after the completion of the PFIN } \\
\text { (Cumming \& Fischer, 2012) }\end{array}$ \\
\hline Growth & $\begin{array}{l}\text { PFIN activities boost economic growth through injection of financial support for } \\
\text { the participating organisations, improved efficiency of innovation activities } \\
\text { (Maroto et al., 2016), increased sales of participating firms (Cumming \& Fischer, } \\
\text { 2012), and related growth in the wider industry sector. }\end{array}$ \\
\hline $\begin{array}{l}\text { Innovation goals of } \\
\text { the PFIN }\end{array}$ & $\begin{array}{l}\text { PFIN-specific output criteria based on the specific policy goals it implements } \\
\text { (Matinheikki et al., 2017) }\end{array}$ \\
\hline
\end{tabular}


Table 3: Case PFIN participating organisations

\begin{tabular}{|c|c|}
\hline Organisation & PFIN projects \\
\hline EM1: 14,400 employees, 3.4B€ revenue & $1,6,8,10$ \\
\hline EM2: 65 employees, privately owned & 2 \\
\hline EM3: 6 employees, privately owned & 5 \\
\hline EM4: 250 employees, privately owned & 6 \\
\hline EM5: 20 employees, privately owned & 6 \\
\hline EM6: 9 employees, privately owned & 7 \\
\hline EM7: 17,300 employees, $2.7 \mathrm{~B} €$ revenue & $7,10,12$ \\
\hline EM8: 1000 employees & 9 \\
\hline EM9: 5000 employees, 1.4 M€ revenue & 11,13 \\
\hline EM10: 2700 employees, 800M€ revenue & 12 \\
\hline Owner $1: 88,000$ employees, $26 \mathrm{~B} €$ revenue & $1,2,11,12$ \\
\hline Owner2: 4 employees, privately owned & 4 \\
\hline Owner3: 3,500 employees, 600M€ revenue & 4 \\
\hline Owner4: 170 employees, privately owned & 5 \\
\hline Owner5: 900 employees, $130 \mathrm{M} €$ revenue & 5 \\
\hline Owner6: 50 employees, $45 \mathrm{M} €$ revenue & 5 \\
\hline Univeristy1: 6,000 employees & $1,2,3,7,8,9,10,11,12$ \\
\hline Univeristy2: 1,400 employees & 3,14 \\
\hline Unviersity3: 3,800 employees & 4,6 \\
\hline Univeristy4: 5,000 employees & 5 \\
\hline Research1: 3,000 employees & 3 \\
\hline Research2: 1,300 employees & 4,10 \\
\hline Research3: 80 employees & 5 \\
\hline Research4: 1,200 employees & 8,13 \\
\hline Designer1: 80 employees, privately owned & 1,3 \\
\hline Designer2: 140 employees, $12.5 \mathrm{M} €$ revenue & 5 \\
\hline Consultant1: 1 employee, $70,000 €$ revenue & 2 \\
\hline Consultant2: 1,000 employees & 3 \\
\hline Consultant3: 50 employees & 3 \\
\hline Consultant4: 100 employees & 3 \\
\hline Consultant5: 1 employee & 3 \\
\hline Consultant6: 2 employees & 4 \\
\hline Consultant7: 10 employees & 6 \\
\hline Consultant8: 1 employee & 9 \\
\hline Class1: 76,000 employees & 3 \\
\hline Class2: 8,000 employees & 6 \\
\hline Class3: 15 employees & 13 \\
\hline
\end{tabular}


Table 4: Project of case PFIN (abbreviations: EM - Equipment manufacturer, Class Classification society)

\begin{tabular}{|c|c|c|c|c|}
\hline $\begin{array}{l}\text { Proje } \\
\text { ct }\end{array}$ & Brief description & $\begin{array}{l}\text { Performanc } \\
\text { e survey }\end{array}$ & $\begin{array}{l}\text { Relationship } \\
\text { survey }\end{array}$ & $\begin{array}{l}\text { Inter } \\
\text { views }\end{array}$ \\
\hline 1 & $\begin{array}{l}\text { Vessel propulsion system optimisation through } \\
\text { development of controllable pre-swirl fins. }\end{array}$ & $\mathrm{X}$ & $\mathrm{X}$ & $\mathrm{x}$ \\
\hline 2 & $\begin{array}{l}\text { Control software development for dynamic adjustment } \\
\text { of shaft speed according to water flow of any given } \\
\text { propeller. }\end{array}$ & $\mathrm{X}$ & $\mathrm{X}$ & \\
\hline 3 & $\begin{array}{l}\text { Concept development for large volume maritime } \\
\text { transport of road trailers and other rolling cargo. }\end{array}$ & $\mathrm{X}$ & $\mathrm{X}$ & $\mathrm{x}$ \\
\hline 4 & $\begin{array}{l}\text { Development of performance management platform for } \\
\text { decision support for ship management for optimised } \\
\text { energy efficiency. }\end{array}$ & $\mathrm{X}$ & $\mathrm{X}$ & $\mathrm{x}$ \\
\hline 5 & $\begin{array}{l}\text { System development for energy optimization of working } \\
\text { vessels and minor ferries with flexible operation profiles. }\end{array}$ & $\mathrm{X}$ & $\mathrm{X}$ & $\mathrm{x}$ \\
\hline 6 & $\begin{array}{l}\text { Development of new gas valve train to enable the use of } \\
\text { a higher gas pressure in two-stroke gas engines. }\end{array}$ & $\mathrm{x}$ & $\mathrm{x}$ & $\mathrm{x}$ \\
\hline 7 & Burning off all types of fuels within liquid and gasses. & $\mathrm{X}$ & $\mathrm{X}$ & \\
\hline 8 & $\begin{array}{l}\text { Reduction of unburned methane in the exhaust from ship } \\
\text { engines. }\end{array}$ & $\mathrm{X}$ & $\mathrm{X}$ & $\mathrm{x}$ \\
\hline 9 & Development and manufacture liquefaction plants & $\mathrm{X}$ & $\mathrm{X}$ & $\mathrm{X}$ \\
\hline 10 & $\begin{array}{l}\text { Emission reduction through optimised scrubber design } \\
\text { and scrubber system. }\end{array}$ & $\mathrm{X}$ & $\mathrm{X}$ & $\mathrm{x}$ \\
\hline 11 & $\begin{array}{l}\text { Development and validation of new antifouling paint for } \\
\text { slow-steaming container vessels }\end{array}$ & $\mathrm{X}$ & $\mathrm{x}$ & $\mathrm{x}$ \\
\hline 12 & Optimise SCR technology solutions for ships & $\mathrm{X}$ & $\mathrm{X}$ & $\mathrm{X}$ \\
\hline 13 & $\begin{array}{l}\text { Development of encapsulation technology for more } \\
\text { controlled biocide release. }\end{array}$ & $\mathrm{X}$ & $\mathrm{X}$ & $x$ \\
\hline 14 & $\begin{array}{l}\text { Build business cases for in-service support of newly } \\
\text { developed products and parts in other projects. }\end{array}$ & $x$ & $\mathrm{X}$ & $\mathrm{X}$ \\
\hline 15 & Improve energy efficiency of small-craft propellers & $\mathrm{X}$ & & \\
\hline
\end{tabular}


Table 5: Innovation goals of the case PFIN (in order of listing in the case PFIN funding proposal)

\begin{tabular}{|c|c|c|}
\hline PFIN objective & Measure/assessment & Target value \\
\hline \multirow[t]{3}{*}{ Environmental goals } & $\mathrm{CO} 2$ reduction & $30-50 \%$ in comparison to 2008 \\
\hline & SOx reduction & $90 \%$ in comparison to 2008 \\
\hline & NOx reduction & $80 \%$ in comparison to 2008 \\
\hline \multirow[t]{3}{*}{ Innovation goals } & Green innovation model & Enabling fast-tracking of ideas in to solutions \\
\hline & Market readiness & $\begin{array}{l}75 \% \text { of initiated technology projects resulting in } \\
\text { commercial products or new development } \\
\text { projects within } 4-5 \text { years }\end{array}$ \\
\hline & Successful solutions & $\begin{array}{l}\text { Proven new concepts. New project technologies } \\
\text { able to obtain verification and documentation of } \\
\text { results }\end{array}$ \\
\hline \multirow[t]{2}{*}{ Growth } & Jobs & Number of jobs at least preserved \\
\hline & Sales increase & $\begin{array}{l}\text { At least } 50 \% \text { of participating companies increase } \\
\text { turnover related to initiated projects }\end{array}$ \\
\hline \multirow[t]{2}{*}{ Research impact } & PhDs & $\begin{array}{l}\text { Number of graduated PhD students within } \\
\text { network duration }\end{array}$ \\
\hline & Researchers to industry & 5 PhDs from projects hired in industry \\
\hline \multirow[t]{3}{*}{ Educational impact } & Master degrees & $24 \mathrm{MSc}$ theses \\
\hline & Practitioners upgraded & $\begin{array}{l}\text { 5-10 people per key partner company trained in } \\
\text { new technology }\end{array}$ \\
\hline & New university courses & 3 new courses \\
\hline \multirow[t]{2}{*}{ Dissemination reach } & Scientific publications & 35 within duration of case PFIN \\
\hline & $\begin{array}{l}\text { Workshops/conferences } \\
\text { created and held }\end{array}$ & 4 within duration of case PFIN \\
\hline \multirow[t]{2}{*}{ International reach } & $\begin{array}{l}\text { International input in all } \\
\text { work packages }\end{array}$ & $\begin{array}{l}\text { Presentation at } 10 \text { international seminars and } \\
\text { conferences }\end{array}$ \\
\hline & $\begin{array}{l}\text { Participation in global } \\
\text { studies }\end{array}$ & International maritime environmental work \\
\hline \multirow[t]{3}{*}{ Effective partnering } & Good cooperation & $\begin{array}{l}\text { Better connections between PFIN partners and } \\
\text { industry }\end{array}$ \\
\hline & Capability of network & $\begin{array}{l}\text { Participation in non-optional and optional } \\
\text { meetings }\end{array}$ \\
\hline & $\begin{array}{l}\text { Knowledge sharing and } \\
\text { competence building }\end{array}$ & Workshop participation of all key partners \\
\hline
\end{tabular}


Table 6: Case PFIN performance according to project

\begin{tabular}{|c|c|c|c|c|c|c|c|c|c|c|c|c|c|c|c|c|c|c|c|c|c|c|}
\hline \multirow[b]{3}{*}{$\begin{array}{l}\text { Project } \\
\text { number - } \\
\text { short title }\end{array}$} & \multirow{3}{*}{ 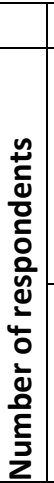 } & \multicolumn{6}{|c|}{ Innovation capabilities } & \multicolumn{3}{|c|}{ Network capabilities } & \multicolumn{2}{|c|}{ Efficiency } & \multicolumn{3}{|c|}{ Growth } & \multicolumn{3}{|c|}{ Emission reduction } & \multicolumn{4}{|c|}{ Dissemination } \\
\hline & & $\begin{array}{l}\stackrel{n}{ \pm} \\
\stackrel{0}{0} \\
\stackrel{0}{0} \\
0\end{array}$ & 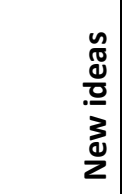 & 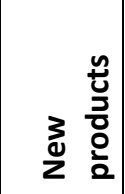 & 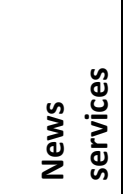 & 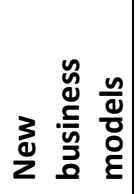 & $\begin{array}{l}n \\
\frac{n}{3} \\
\frac{1}{4} \\
\frac{1}{0} \\
\tilde{n}\end{array}$ & 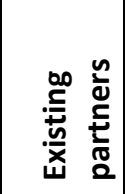 & $\begin{array}{ll} & \frac{n}{d} \\
3 & \stackrel{ \pm}{\frac{ \pm}{\pi}} \\
2 & \frac{2}{2}\end{array}$ & 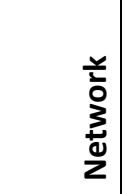 & $\stackrel{\text { E }}{\mathrm{E}}$ & 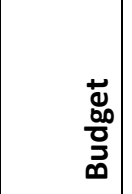 & 응 & 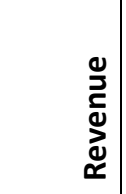 & 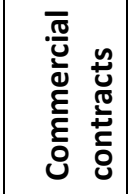 & ồ & ồ & Оิ & 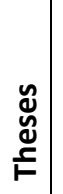 & 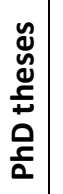 & 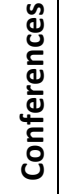 & $\frac{\frac{1}{0}}{\frac{\pi}{2}}$ \\
\hline & & 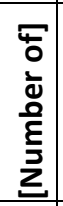 & 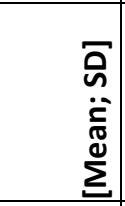 & 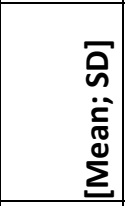 & 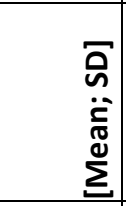 & 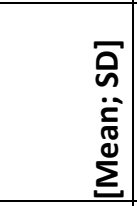 & 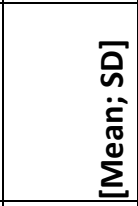 & 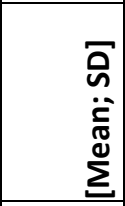 & 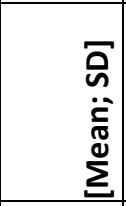 & 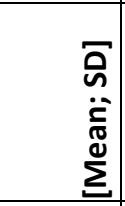 & 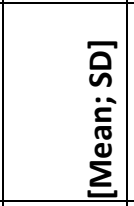 & 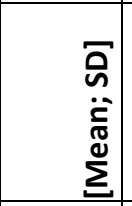 & 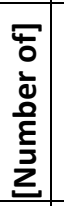 & 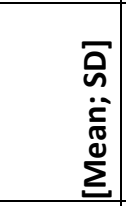 & 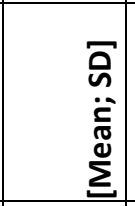 & 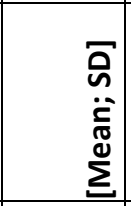 & 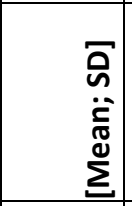 & 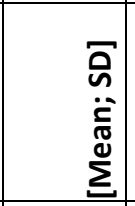 & $\begin{array}{l}\frac{5}{0} \\
\frac{1}{d} \\
\frac{0}{E} \\
\frac{E}{3} \\
z\end{array}$ & 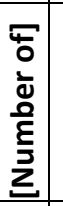 & $\begin{array}{l}\text { 它 } \\
\frac{1}{ \pm} \\
\frac{0}{\varepsilon} \\
\frac{5}{3} \\
\underline{z}\end{array}$ & $\begin{array}{l}\text { Tั } \\
\frac{1}{d} \\
\frac{0}{E} \\
\frac{5}{3} \\
z\end{array}$ \\
\hline $\begin{array}{l}1-\text { Pre-swirl } \\
\text { fins }\end{array}$ & 5 & 1 & $3.6 ; 1.1$ & $3.6 ; 1.1$ & $2.4 ; 1.1$ & $3.1 ; 1.0$ & $1.60 ; 0.6$ & $4.0 ; 1.0$ & $3.0 ; 1.1$ & $2.2 ; 1.1$ & $2.6 ; 1.5$ & $4.0 ; 1.0$ & 3 & $2.5 ; 1.0$ & $3.3 ; 0.5$ & $1.3 ; 1.3$ & $4.0 ; 1.0$ & $1.7 ; 1.2$ & 5 & 1 & 0 & 2 \\
\hline $\begin{array}{l}\text { 2-Dynamic } \\
\text { propeller }\end{array}$ & 2 & 0 & $0 ; 0$ & $4.5 ; 0.7$ & $2.0 ; 1.4$ & $2.3 ; 0.4$ & $5 ; 2.1$ & $3.3 ; 1.1$ & $2.5 ; 1.4$ & $1.5 ; 0.7$ & $3.5 ; 2.1$ & $4.5 ; 0.7$ & 2 & $2.0 ; 1.4$ & $3.0 ; 0$ & $1.0 ; 0$ & $3.5 ; 2.1$ & $1.0 ; 0$ & 1 & 0 & 4 & 0 \\
\hline 3 - Trailer cat & 8 & 0 & $3.4 ; 1.3$ & $3.0 ; 1.1$ & 2.8 & $9 ; 0.6$ & $1 ; 0.8$ & $3.3 ; 0.9$ & $3.4 ; 0.9$ & $2.6 ; 1.3$ & $3.7 ; 1.0$ & $4.6 ; 0.5$ & 0 & $2.9 ; 0.4$ & $2.9 ; 0.4$ & $1.5 ; 1.4$ & $4.0 ; 1.0$ & $2.5 ; 1.0$ & 14 & 0 & 6 & 1 \\
\hline $\begin{array}{l}4 \text { - Decision } \\
\text { support }\end{array}$ & 7 & 0 & $4.1 ; 0.9$ & $3.9 ; 1.5$ & $4.3 ; 0.8$ & $3.0 ; 0.6$ & $4.1 ; 1.0$ & $3.1 ; 1.0$ & $4.1 ; 1.0$ & $1.4 ; 1.1$ & $3.5 ; 1.4$ & $4.7 ; 0.5$ & 5 & $2.7 ; 1.1$ & $2.1 ; 0.9$ & $2.6 ; 1.1$ & $4.0 ; 0.8$ & $2.4 ; 0.8$ & 8 & 0 & 17 & 2 \\
\hline $\begin{array}{l}5-\text { Monitor } \\
\text { performance }\end{array}$ & 3 & 0 & $3.0 ; 1.0$ & $2.7 ; 1.5$ & $2.3 ; 1.5$ & $2.7 ; 0.6$ & $1.7 ; 1.3$ & $3.7 ; 1.3$ & $4.2 ; 0.8$ & $2.7 ; 1.2$ & $3.0 ; 0$ & $4.0 ; 1.0$ & 0 & $3.0 ; 1.7$ & $2.3 ; 0.6$ & $3.0 ; 0$ & $2.5 ; 0.7$ & $3.0 ; 0$ & 3 & 3 & 6 & 2 \\
\hline 6 -Valve train & 5 & 0 & $3.2 ; 0.8$ & $2.4 ; 1.8$ & $2.6 ; 0.6$ & $0 ; 1.0$ & $8 ; 1.1$ & $3.4 ; 0.7$ & $3.2 ; 1.4$ & $1.6 ; 0.9$ & $3.0 ; 0$ & \begin{tabular}{|l|}
$3.8 ; 1.1$ \\
\end{tabular} & 03 & $3.0 ; 2.0$ & $2.7 ; 1.5$ & $1.3 ; 1.5$ & $2.5 ; 0.7$ & \begin{tabular}{|l|}
$2.0 ; 1.4$ \\
\end{tabular} & 0 & 0 & 0 & 0 \\
\hline $\begin{array}{l}7-\text { Multi-fuel } \\
\text { burner }\end{array}$ & 4 & 0 & $3.5 ; 1.0$ & $4.0 ; 1.4$ & $2.5 ; 1.3$ & $3.4 ; 1.3$ & $1.0 ; 0$ & $3.3 ; 0.3$ & $3.6 ; 0.3$ & $1.8 ; 1.0$ & $4.0 ; 0$ & $4.3 ; 0.6$ & 4 & $4.0 ; 1.4$ & $2.0 ; 1.4$ & $1.8 ; 2.4$ & $3.5 ; 2.1$ & $2.5 ; 0.7$ & 4 & 0 & 2 & 0 \\
\hline $\begin{array}{l}8 \text { - Methane } \\
\text { reduction }\end{array}$ & 2 & 0 & $4.0 ; 0$ & $3.5 ; 0.7$ & $4.0 ; 0$ & $3.0 ; 0.7$ & $1.0 ; 0$ & $3.8 ; 0.4$ & $4.0 ; 0.7$ & $3.0 ; 1.4$ & $3.0 ; 2.8$ & $4.5 ; 0.7$ & 0 & $4.0 ; 0$ & $3.0 ; 0$ & $\mathrm{~N} / \mathrm{A}$ & $\mathrm{N} / \mathrm{A}$ & $2.0 ; 0$ & 2 & 0 & 0 & 0 \\
\hline $\begin{array}{l}9- \\
\text { Liquefaction }\end{array}$ & 3 & 0 & $4.3 ; 0.6$ & $2.7 ; 2.5$ & $4.0 ; 1.0$ & $3.0 ; 0$ & $2.7 ; 0.6$ & $3.7 ; 0.6$ & $3.8 ; 1.0$ & $1.3 ; 0.6$ & $4.0 ; 1.4$ & $3.7 ; 0.6$ & 9 & $2.7 ; 1.5$ & $3.0 ; 1$ & $3.0 ; 1.4$ & $3.7 ; 1.5$ & $2.5 ; 2.1$ & 2 & 0 & 14 & 0 \\
\hline $10-$ Scrubber & 2 & 5 & $3.5 ; 0.7$ & $0 ; 0$ & $2.5 ; 0.7$ & $3 ; 0.4$ & $0 ; 1.4$ & $4.5 ; 0.7$ & $3.8 ; 0.4$ & $1.0 ; 0$ & $3.5 ; 0.7$ & $4.5 ; 0.7$ & 4 & $3.0 ; 0$ & $2.5 ; 0.7$ & $3.0 ; 0$ & $3.0 ; 0$ & $3.0 ; 0$ & 0 & 0 & 0 & 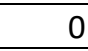 \\
\hline $\begin{array}{l}11- \\
\text { Antifouling } \\
\text { paint }\end{array}$ & 2 & 0 & $4.0 ; 0$ & $2.5 ; 0.7$ & $1.0 ; 0$ & $1.5 ; 0.7$ & $1.5 ; 0.7$ & $5.0 ; 0$ & $4.8 ; 0.4$ & $1.5 ; 0.7$ & $3.0 ; 0$ & $4.5 ; 0.7$ & 1 & $\mathrm{~N} / \mathrm{A}$ & N/A & $\mathrm{N} / \mathrm{A}$ & $\mathrm{N} / \mathrm{A}$ & N/A & 4 & 0 & 4 & 0 \\
\hline
\end{tabular}




\begin{tabular}{|c|c|c|c|c|c|c|c|c|c|c|c|c|c|c|c|c|c|c|c|c|c|c|}
\hline $\begin{array}{l}12-\mathrm{NOx} \\
\text { reduction }\end{array}$ & 4 & 5 & $3.8 ; 1.3$ & $3.3 ; 0.5$ & $3.0 ; 1.1$ & $3.0 ; 0.7$ & $2.3 ; 1.0$ & $4.4 ; 1.0$ & $4.3 ; 1.1$ & $1.3 ; 0.5$ & $3.8 ; 0.5$ & $4.3 ; 0.5$ & 9 & $3.0 ; 1.6$ & $2.3 ; 1.0$ & $\mathrm{~N} / \mathrm{A}$ & $\mathrm{N} / \mathrm{A}$ & $\mathrm{N} / \mathrm{A}$ & 4 & 0 & 3 & 0 \\
\hline 13 - Biocides & 2 & 0 & $4.0 ; 0$ & $1.5 ; 0.7$ & $3.0 ; 2.8$ & $1.0 ; 0$ & $1.0 ; 0$ & $5.0 ; 0$ & $3.8 ; 1.1$ & $1.5 ; 0.7$ & $4.5 ; 0.7$ & $4.0 ; 0$ & 1 & $\mathrm{~N} / \mathrm{A}$ & $\mathrm{N} / \mathrm{A}$ & $\mathrm{N} / \mathrm{A}$ & $\mathrm{N} / \mathrm{A}$ & $\mathrm{N} / \mathrm{A}$ & 1 & 0 & 4 & 0 \\
\hline $\begin{array}{l}14- \\
\text { Servitization }\end{array}$ & 3 & 0 & $3.3 ; 1.2$ & $3.3 ; 0.6$ & $3.3 ; 1.2$ & $2.7 ; 0.3$ & $3.3 ; 0.6$ & $3.8 ; 0.3$ & $3.2 ; 1.3$ & $2.0 ; 0$ & $3.3 ; 0.6$ & $4.0 ; 1.0$ & 3 & $3.3 ; 0.6$ & $2.7 ; 0.6$ & $2.0 ; 1.7$ & $2.0 ; 1.7$ & $1.7 ; 1.5$ & 1 & 0 & 3 & 3 \\
\hline $\begin{array}{l}15 \text { - Vanish } \\
\text { prop }\end{array}$ & 2 & 0 & $3.0 ; 0$ & $3.0 ; 0$ & $3.0 ; 1.4$ & $2.8 ; 1.0$ & $2.0 ; 1.4$ & $5.0 ; 0$ & $4.8 ; 0.4$ & $1.0 ; 0$ & $4.5 ; 0.7$ & $5.0 ; 0$ & 0 & $2.0 ; 2.8$ & $1.0 ; 1.4$ & $\mathrm{~N} / \mathrm{A}$ & $\mathrm{N} / \mathrm{A}$ & $2.0 ; 0$ & 1 & 0 & 2 & 0 \\
\hline $\begin{array}{l}\text { Network } \\
\text { total/average }\end{array}$ & & 6 & 3.7 & 3.1 & 2.9 & 2.7 & 2.1 & 3.9 & 3.8 & 1.8 & 3.5 & 4.3 & 37 & 2.9 & 2.5 & 2.0 & 3.3 & 2.2 & 22 & 35 & 62 & 21 \\
\hline
\end{tabular}

Table 7: Linking network performance to inter-organisational relationships

\begin{tabular}{|c|c|c|c|c|c|c|c|c|c|c|c|c|c|c|c|c|c|c|c|c|c|}
\hline & \multicolumn{6}{|c|}{ Innovation capabilities } & \multicolumn{3}{|c|}{$\begin{array}{c}\text { Network } \\
\text { capabilities }\end{array}$} & \multicolumn{2}{|c|}{ Efficiency } & \multicolumn{3}{|c|}{ Growth } & \multicolumn{3}{|c|}{$\begin{array}{l}\text { Emission } \\
\text { reduction }\end{array}$} & \multicolumn{4}{|c|}{ Dissemination } \\
\hline & 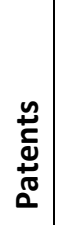 & 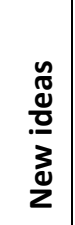 & 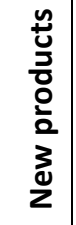 & 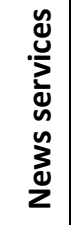 & 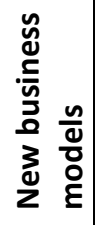 & $\begin{array}{l}\frac{n}{2} \\
\frac{0}{1} \\
\frac{1}{\pi} \\
\tilde{n}\end{array}$ & 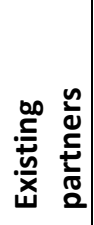 & 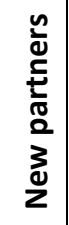 & 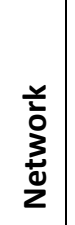 & $\stackrel{\mathscr{\Xi}}{\mathfrak{E}}$ & 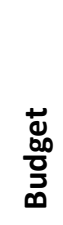 & 응 & 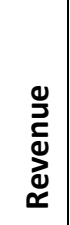 & 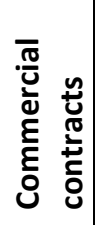 & ồ & ồ & Оิ & 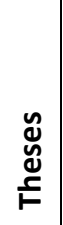 & 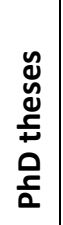 & 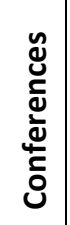 & 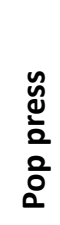 \\
\hline $\begin{array}{l}\text { Inter-organisational relationship } \\
\text { pattern }\end{array}$ & 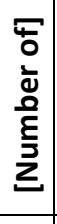 & 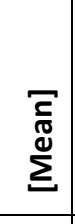 & 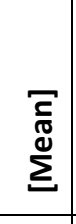 & 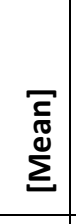 & 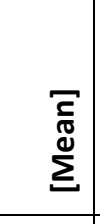 & $\begin{array}{l}T \\
\frac{D}{\pi} \\
\stackrel{d}{\Sigma}\end{array}$ & 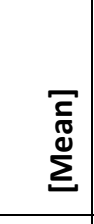 & 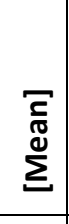 & $\begin{array}{l}\underline{I} \\
\mathbb{J} \\
\stackrel{d}{J}\end{array}$ & $\begin{array}{l}\text { হ } \\
\frac{0}{0} \\
\stackrel{0}{\Sigma}\end{array}$ & 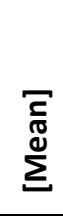 & $\begin{array}{l}\text { 它 } \\
\frac{1}{d} \\
\frac{\delta}{\varepsilon} \\
\frac{5}{3} \\
z\end{array}$ & 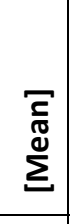 & $\begin{array}{l}\widetilde{c} \\
\mathbb{D} \\
\stackrel{\mathbb{d}}{\Sigma}\end{array}$ & 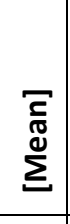 & 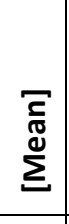 & 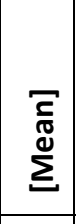 & 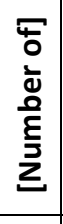 & $\begin{array}{l}\text { 它 } \\
\frac{1}{d} \\
\frac{\delta}{\varepsilon} \\
\frac{5}{3} \\
z\end{array}$ & 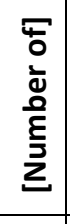 & $\begin{array}{l}\text { प్ర } \\
\frac{1}{d} \\
\frac{0}{E} \\
\frac{5}{3}\end{array}$ \\
\hline 1) Functional relationships & 11 & 3.7 & 3.1 & 2.7 & 2.8 & 1.6 & 4.2 & 3.7 & 1.5 & 3.7 & 4.2 & 21 & 3.1 & 2.5 & 2.0 & 3.5 & 2.4 & 14 & 1 & 9 & 2 \\
\hline 2) Dysfunctional relationships & 0 & 3.7 & 3.6 & 3.2 & 2.7 & 2.7 & 3.5 & 3.6 & 2.1 & 3.3 & 4.3 & 10 & 3.0 & 2.6 & 2.1 & 3.0 & 2.0 & 15 & 3 & 30 & 7 \\
\hline 3) Anarchic relationships & 0 & 3.7 & 2.6 & 2.6 & 2.6 & 2.0 & 3.8 & 3.8 & 1.8 & 3.4 & 4.2 & 10 & 2.8 & 2.8 & 1.9 & 3.4 & 2.3 & 20 & 0 & 24 & 13 \\
\hline
\end{tabular}




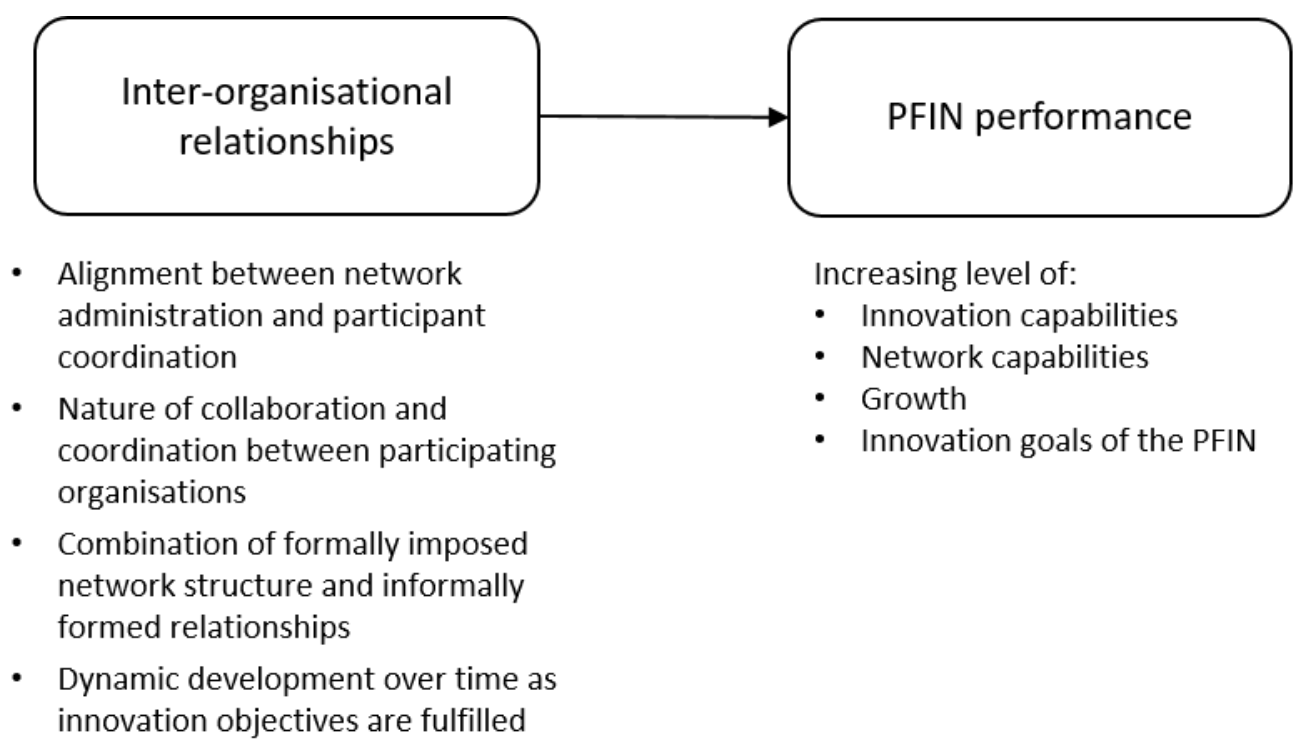

Figure 1: Conceptual framework for our investigation

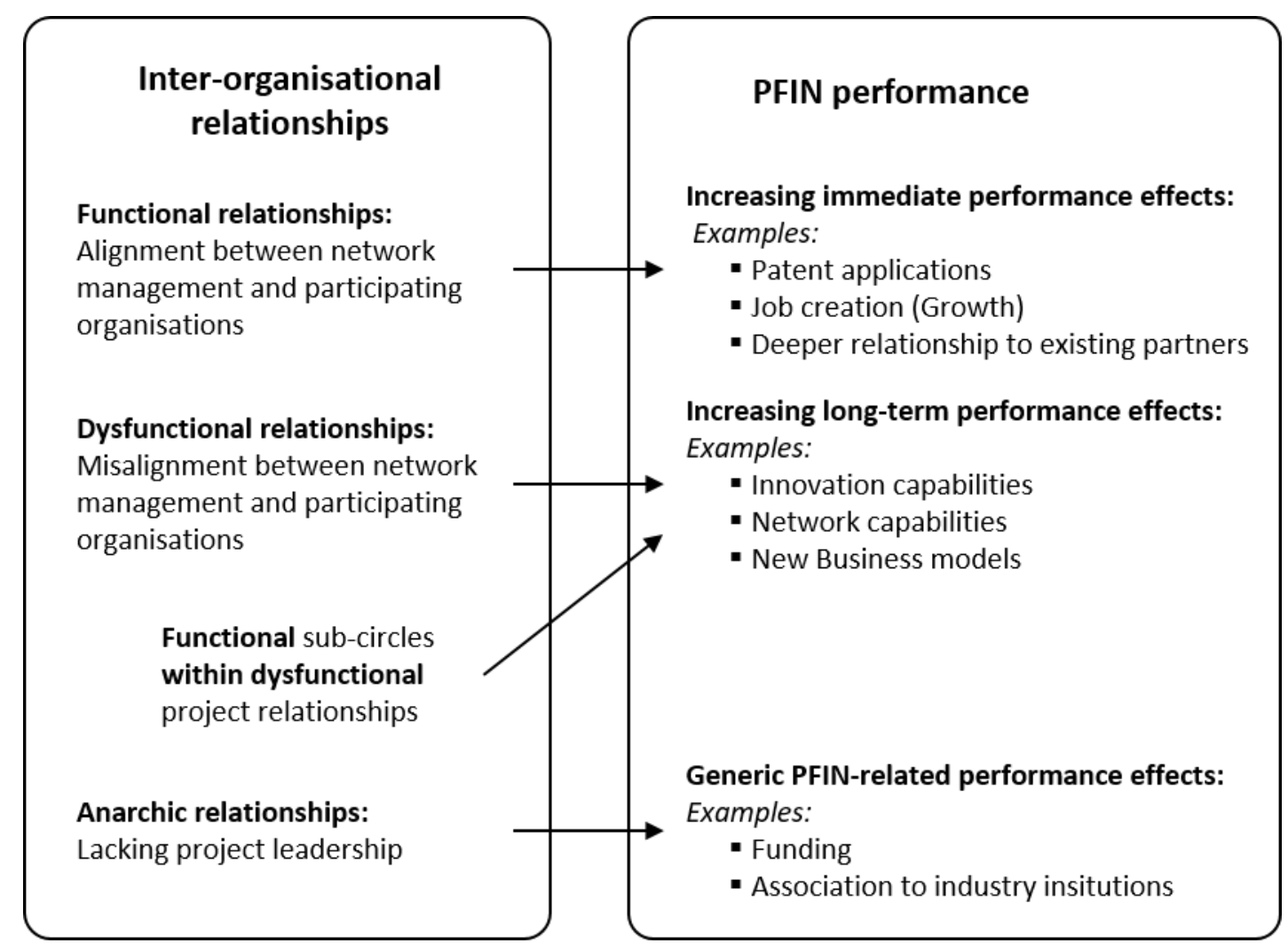

Figure 2: Proposed conceptual framework of the performance effects of interorganisational relationships in PFINs 